\title{
Understanding the Human Condition through the Depiction of Protagonists in Crime and Mystery Novels
}

\author{
Kevalin Kaewruean \\ Asst. Prof., English Department, Faculty of Humanities, Chiang Mai \\ University, Chiang Mai, Thailand \\ gaegdgd@gmail.com
}

\begin{abstract}
Extant criticism of crime and mystery fiction has indicated how protagonists have freedom of choice in dealing with difficult situations in different forms of risky or challenging settings. In this article, previous criticism is evaluated in terms of its reflection of an essential element of the human condition: the Self's free will to construct the existential and spatial meanings of its phenomenological existence in relation to the Other. The article further indicates that protagonists tend to disregard their freedom and responsibility for their actions, especially when they make existential choices in traumatic or critical situations. Additionally, the dominance of others and variously suppressive spatial contexts can inhibit the protagonists from acknowledging their free will to act responsibly in order to reach their authentic existence. This article integrates Jean Paul Sartre's concept of the human condition and the corresponding interpretative framework of spatial concepts from different thinkers, such as Edward Relph, Arnold van Gennep, Victor W. Turner and Mikhail M. Bakhtin, who emphasize the significance of places in the meaning-construction of the Self's identity and its existence in relation to the Other. Through the integration of these theoretical frameworks, the portrayal of protagonists in contemporary crime and mystery novels is examined in order to illustrate individuals' senses of freedom and responsibility for their own actions in existential and spatial contexts.
\end{abstract}

\section{Keywords}

crime - human condition - mystery - protagonists - Sartre - space 
Reading crime and mystery stories can encourage readers to critically analyze how characters make choices, especially in critical situations. Choices that detective protagonists make in solving crime mysteries may reflect their identities as strong and intelligent individuals. Villainous characters' decisions to kill or their desires to commit serious crimes may help construct their identities as brutal and manipulative individuals. Victimized characters may appear to have a low sense of esteem to defend themselves, making other characters perceive them as incompetent and submissive. A character's free will to act in response to any given situation can reflect the significance of the Self's freedom in constructing its entities and existence in relation to others and society. All types of characters in crime and mystery stories, to an extent, are depicted with the desire or attempt to gain a sense of freedom in order to complete their acts, goals or quests. Characters may also express their fear, anguish or despair while making hard choices as they may perceive their situations to be uncontrollable, unpredictable or unsolvable. The depiction of characters in crime and mystery fiction can reflect the Self's autonomy or its sense of freedom in terms of the existential construction of its existence. Jean Paul Sartre (1948, 50 ) indicates that one of the most important elements of the human condition is that individuals have freedom of choice in the construction of their being. Their choices, thus, determine who they are. Sartre $(2007,44)$ notes that we can never avoid making choices: "I can always choose, but I must realize that, if I decide not to choose, that still constitutes a choice."

Through observation of previous criticism related to crime and mystery fiction, it can be seen that many critics indicate how protagonists of this genre are depicted with a relatively high degree of freedom in dealing with risky or critical situations; they are also capable of solving difficult problems or crime mysteries. Previous criticism has also flagged certain characteristics of the protagonists, such as physical/mental strength, independence, intelligence and their potential to use exceptional skills. These characteristics can enhance the protagonists' sense of freedom in coping with their opponents or life-threatening circumstances (Chapman 2004, 213-217; Gregoriou 2007, 141-144, 146-148; Hoffman 2016, 64-65; Horsley 2005, 24, 33-34, 135136; Macleod 1994, 41; Makinen 20o6, 150-152; Knight 1980, 83; Knight 2004, 167-170; Routledge 2010, 325-329; Scaggs 2005, 26-28, 59-6o). For instance, Christopher Routledge (2010, 325-326) points out that in "The Hardy Boys" series (1927-2005), (one of the most highly regarded series for young readers of all time), male characters are depicted with a large degree of freedom of 
choice. "The Hardy Boys" presents outstanding aspects of the main characters, for example, their freedom to have an adventure in various places and their extraordinary capability to use vehicles and technology. Routledge (2010, 326) comments, "the Hardy Boys offered their fans a fantasy of freedom, autonomy, and a life that took advantage of every technology the modern world had to offer." Lee Horsley $(2005,22)$ also notes that in Sir Arthur Conan Doyle's outstanding works, The Adventures of Sherlock Holmes (1892) and The Memoirs of Sherlock Holmes (1894), Holmes, is depicted with specialized skills, which show his rationality and autonomy when coping with crime-related events. Doyle presents the character as having both great skills and knowledge of science, which are both utilized in crime investigation for explaining obscurity and identifying hidden crimes and their causes. Horsley $(2005,24)$ indicates that in order to solve crime mysteries, Holmes can create a theory of deductive reasoning and form a chain of reasoning which enable him to solve his criminal cases. Holmes can change indeterminacy into determinacy, narrow down the possibilities and punish the criminal agent in the end. Stephen Knight (1980, 83) comments, "Holmes's power to evaluate is ratified by his wide experience as well as his personal authority. He is in touch with all levels of society."

In addition, several critics have noted that many places in crime and mystery fiction narratives are depicted as containing unsafe spaces, where social disorder or moral corruption becomes apparent. Protagonists can experience a spatial sense of alienation; moreover, their sense of freedom is diminished in this kind of oppressive space, which is usually presented in urban locations (Ascari 2007, 163-165; Bertens and D'haen 2001, 120-121; Horsley 2005, 29-30; Woolf 1988, 131-136). For instance, Mike Woolf $(1988,133)$ indicates that in Jerome Charyn's work, the perception of reality is presented through dislocated space, violence, terror and loneliness. Charyn portrays an image of New York City as an ethnic society where different tribal communities coexist under a system in which spatial borderlines between decency and evil become obscured. Only criminals and police exist in the city (Woolf 1988, 134-135). Woolf $(1988,138)$ notes how Detective Isaac, the protagonist in Charyn's Secret Isaac (1978), perceives the unpleasant city he lives in with a sense of alienation and absurdity: "Isaac perceives that the police are part of a deranged cosmos, and yet, as the philosopher-cop, he continues to act as if there existed the possibility of redemption and salvation. As a would-be protector of the dispossessed, he walks in the land of the dead, a doomed futile figure carrying within a tapeworm which is his own sense of guilt, impotence and suffering." Hans Bertens and Theo D'haen (2001, 120-121) also indicate that the United 
States, as a whole, is also depicted as a space where purity is destroyed. They comment that in the work of George P. Pelecanos, America becomes a space of the grotesque, as depicted in the "Nick Stefanos Series" (1992-1995). Pelecanos demonstrates how the protagonist, Nick Stefanos, lives in a perceived helllike world, where his degradation is unending; the United States, Nick's background origin, forms an unpleasant space where people's inter-generational relationships are unsatisfying. A Firing Offense, for instance, conveys a critique of contemporary America, which depicts an unlivable place through the loss of innocence, youth and the corresponding problems of corruption, drugs and hypocrisy.

Apart from the critiques of urban locations as dangerous zones in crime and mystery writing, critics indicate that natural settings can also be harmful and unpredictable. However, protagonists can still maintain their spatial autonomy in overcoming different forms of natural hazards and in situating natural spaces for their own advantage or benefit (Blum 2010, 90-92; Leane 2016, 30-39). Through their adventures or experiences in a variety of unsafe settings, protagonists can display their spatial freedom as a panacea for difficult situations (Blum 2010, 103; Boesky 2010, 190-191). For instance, Elizabeth D. Blum (2010, 90-92) points out that in detective stories aiming at young readers, such as the Tom Swift series of books, a natural space is depicted as a site controlled or manipulated by humans. The life of the protagonist, Tom Swift, is concerned with solving a variety of mysteries and inventing technological gadgets. Natural spaces including the earth, the water and the air are under his control and, also, that of his inventions. Tom, in addition, perceives natural places as a source for gaining wealth. When he travels to the Rocky Mountains, he aims to find diamonds. His trip to Alaska is a search for gold, and in his journey to Africa, Tom desires to hunt elephants for their ivory tusks. Blum $(2010,103)$ states, "the early Tom Swift books stressed domination over nature and the importance of nature's subordination to capitalistic enterprise and technology."

In this article, the previous critiques are accepted as they reflect the idea that individuals' free will or a sense of freedom is significant in the meaning-construction of their existence in relation to other individuals. In this article, Jean Paul Sartre's concept of individuals' senses of freedom and responsibility for their choices is underscored, since free will is regarded as one of the most significant elements of the human condition. However, in contrast to the arguments adumbrated in the literature review, which focus on the protagonists' strong sense of freedom, I argue that through their traumatic experiences, 
protagonists tend to have difficulty in achieving a complete sense of authenticity because they deny taking responsibility for their own actions. In turn, this hinders their overall sense of free will. The denial of individuals' freedom and responsibility for their actions is termed by Sartre as 'bad faith'. Although protagonists in crime and mystery writing seem to have a relatively high degree of freedom, I contend that they also act in bad faith, especially during critical situations in the social and spatial contexts in which they operate. In addition, I argue that the existence of the "Other" and externally oppressive situations and environments can obstruct the protagonists from completely acknowledging the overall important elements of the human condition—or reaching their truly authentic existence.

This article aims to examine the existential and spatial elements of the human condition as reflected in the depiction of protagonists in crime and mystery novels. Six highly acclaimed contemporary novels written by American authors are analyzed to underscore the significant elements of the human condition revealed through the multifaceted protagonists. The selected protagonists are divided into three groups: 1) those who are criminals; 2) those who attempt to solve crime mysteries; and 3) those who are victims of crimes or are unjustly accused of committing crimes. The analysis of these protagonists will reveal whether they successfully acknowledge certain elements of the human condition; that is in terms of 1 ) how the Self has freedom socially and spatially to construct the meaning of its subjectivity and existence in relation to the Other; and 2) how the Self tends to avoid the implications of its own freedom and agency as it experiences a sense of anguish and despair while making existential choices. This article focuses on the depiction of the protagonists during their traumatic experiences, especially with regard to their sense of freedom as a coping mechanism in different social and spatial contexts. Jean Paul Sartre's theoretical framework of the human condition and the interpretative framework of spatial concepts are integrated in order to analyze the six novels. These novels are 1) Scowler by Daniel Kraus (2013); 2) The Walls around Us by Nova Ren Suma (2015); 3) The Interrogation of Gabriel James by Charlie Price (2010); 4) The Silence of Murder by Dandi Daley Mackall (2011); 5) The Sin Eater's Confession by Ilsa J. Bick (2013); and 6) All the Truth That's in Me by Julie Berry (2013). 


\subsection{Jean Paul Sartre's Concept of the Human Condition}

In Being and Nothingness: An Essay on Phenomenological Ontology, Sartre (1958, 98) denotes two modes of consciousness: 'being-for-itself' and 'being-in-itself'. He defines human subjectivity as consciousness, or in his term 'being-for-itself', whose existence depends upon 'being-in-itself' or non-conscious objects, such as rocks and tables. Being-in-itself has a static or self-contained entity since it is "what it is - in the absolute plentitude of its identity". In contrast, 'being-for-itself' is a non-being or nothingness which lacks a permanent sense of identity: "At present, it is not what it is (past) and it is what it is not (future)" (Sartre 1958, 123). That is, the Self or being-for-itself is a free or transcendent agent, perpetually fleeing its past and striving towards a future to establish its own meaning of existence. Human consciousness is not a fixed entity, and its being is also paradoxical: although it founds itself from its past, it is no longer its past self at the present ('it is not what it is') (Sartre 1958, 123). Accordingly, while transcending its past towards the future, the Self is never a complete entity since its future is not yet to come ('it is what it is not') (Sartre 1958, 123). The present and future are never stable for human consciousness, since it becomes its past which is no longer, and once it reaches its future, its future will instantaneously become its past. Therefore, for the construction of its existence, the Self through its freedom must ceaselessly and inevitably make choices in every situation it encounters. It is always burdened with the act of choosing or responding to its situations.

Through this immense freedom and a corresponding sense of indeterminacy, the Self or human consciousness must endlessly make meaning of its existence without any pre-existing guidance or essence. Sartre (1948, 29) believes that "existence is prior to essence"; therefore "man is responsible for what he is." The Self has no essence in itself, or its entity is nothing, so it must be conscious of something in order to construct its being. As Sartre (2001, 10) notes, "All consciousness is consciousness of something." The Self first exists and freely makes choices in the world or in relation to being-in-itself. Thus, the essence of human consciousness is determined by its own freedom and also the facticity in which the Self has no control, such as its birth. Sartre (1948, 26-27) believes that the Self is formed in flux, and its imperative project is to create its own essence through prior nothingness in its entity after it comes out into the alienating world of contingency. Therefore, the Self is its own artisan, and its essence is its intended artifact.

In order to escape from this sense of anguish, abandonment or contingency, the Self tends to act in "bad faith." Sartre $(1958,47-70)$ indicates that bad faith 
occurs when individuals refuse to acknowledge their freedom and responsibility for choice making. Human consciousness desires to be the in-itself-for-itself or to possess a complete essence of its own being so as not to endlessly make choices for the meaning construction of its being and situations. To be self-identical or to solidify its essence entirely can help lessen anguish and can allow the Self to escape from the undesirable condition of questioning its own identity.

Sartre's concept of human consciousness and the relationships between the Self and the Other reflects significant aspects of the human condition. The Self is endowed with the freedom and responsibility to construct the meaning of its own existence.The Self can also interpret its own situations in relation to the Other differently, depending on its own free will. Nevertheless, through this arduous project, as a creator of its own entity, the Self can feel anguish and can act in bad faith or deny its own freedom in various forms and in various ontological contexts. The Self's sense of autonomy can be unstable when interacting with the Other, since it can be devalued or objectified through the Other's gaze. The relationship between the Self and the Other can be either conflicted or harmonized, depending on the awareness of both participants' potential to reach authentic existence — or the ways they would choose to construct their situations - with or without active responsibility.

\subsection{The Interpretative Framework of Spatial Concepts}

Places have become an essential part of human existence; they are not merely material settings or geographical indicators of locations but can significantly contribute to the spatial construction of human subjectivity and relationships. Therefore, understanding places and how we are related to them can be worthwhile and can allow us to critically evaluate ourselves, the Other and the world through multi-faceted spatial standpoints. Individuals may, in various ways, develop their sense of place or "topophilia," a term defined by Yi-Fu Tuan (1974, 93) as a psychological bond between humans and the material environment. Tuan $(1974,247)$ indicates that through our connection with places, we can gain transient visual pleasure or sensual delight. We also favor certain places since they can make us feel at home; they embody experiences of our past or they kindle our sense of belonging and creativity. The spatial construction of our entities will continue and can be interpreted endlessly as long as we exist; it is thus significant in comprehending how our existence is related to various places.

In Place and Placelessness, Edward Relph $(1976,49)$ indicates his concept of "existential insideness" and "existential outsideness." When individuals are existentially inside a particular place, they have a sense of belonging and 
can identify themselves with their situated space. The place becomes important and meaningful through their full experience even when they have no premeditated or self-conscious reflection. Experiencing a place through the perception of existential insideness, individuals become part of the place and vice versa. Thus, individuals who do not have a place that they can relate to or identify with can be regarded as rootless or homeless (Relph 1976, 55). As Relph $(1976,55)$ comments, "Existential insideness characterizes belonging to a place and the deep and complete identity with a place that is the very foundation of the place concept." Contrastively, to experience existential outsideness with regard to a place, individuals lack a spatial sense of belonging, self-consciously and self-reflectively feeling alienated from the place as well as the people situated in it. These places offer meanings in which the individuals fail to engage themselves, making them experience the world as an unreal space. These places become mere backdrops with actions perceived as senseless, illusory and vacant (Relph 1976, 51).

Apart from perceiving space in the modes of the existential insideness and outsideness, sometimes we can also experience space which is in-between or liminal. According to Arnold van Gennep (1960, 189-19o), individuals are in a transitional or liminal state, when they change from one stage of life to another. There are always thresholds for individuals to cross so that they can be united into a new world; this spatial notion can be depicted in various aspects of life, such as adolescence, maturity, birth, death and the afterlife. As van Gennep (196o, 189) comments, “...life itself means to separate and to be reunited, to change form and condition, to die and to be reborn. It is to act and to cease, to wait and rest, and then to begin acting again, but in a different way." Victor W. Turner (1969, 94-95), who later developed van Gennep's concept of liminality, also indicates that before individuals reach the liminal state or "margin", they abandon their social conditions or any form of social structure. Their being, thus, becomes obscure since they lack definite social identities or rules to define who they are. "Liminal entities are neither here nor there; they are betwixt and between the positions assigned and arrayed by law, custom, convention, and ceremonial," comments Turner $(1969,95)$.

The notion of liminality can further be related to Mikhail M. Bakhtin's concept of the carnivalesque, which presents the world as a chaotic space due to the temporal suspension of social order, hierarchy or rules. For instance, during the carnival, ordinary social norms or ranks become reversed: low ranking or outcast individuals, such as fools and beggars, take significant roles of the intellect or leaders, whereas high ranking individuals, such as kings and noblemen, play the degraded roles of poor, misfortunate or insane individuals (Bakhtin 1984, 10-11). Hence, in the space of 
the carnivalesque, individuals can become free and dissolve their socially stratified identities when interacting with one another. Bakhtin comments that vitality and spontaneous creativity can be constructed during the carnival due to an active engagement among participants. "This carnival spirit offers the chance to have a new outlook on the world, to realize the relative nature of all that exists, and to enter a completely new order of things," states Bakhtin (1984, 34).

Places can be influential in forming the meanings of individuals' entities and their perceptions towards the Other as well as the social contexts in which they are diversely situated. Individuals' affective connection to places or "topophilia" can allow them to experience different spatial forms of pleasant moments in their lives. A sense of belonging can also be created through their attachment of places in the mode of "existential insideness", whereas their strong sense of estrangement can be stimulated when they perceive places as zones of "existential outsideness." Apart from being in and out of places, individuals can experience the space of liminality and the carnivalesque, where the status quo and their entire beings become equivocal and vulnerable, allowing creativity, freedom, rebellion or even dangers into the construction of their ontological existence. It is thus essential for individuals to be able to encounter different aspects of spatial realities within the realm of their genuine decisions and their active responsibilities so as to establish a meaningful space in which they and the Other can harmoniously coexist.

The Depiction of Protagonists in Contemporary Crime and Mystery Novels:

\section{1}

The Protagonists' Existential Condition

The findings in this article reveal that all protagonists have difficulty in acknowledging their sense of freedom for the successful existential and spatial construction of their subjectivity and existence in relation to the Other; moreover, they tend to act in bad faith during their traumatic encounters. That is, they tend to deny any responsibility for their own actions or refuse to accept any unsatisfying results which may stem from their actions, in order to cope with their existential sense of anguish or despair. The criminal protagonists, Ry in Scowler and Violet in The Walls around Us, deny taking full responsibility for their crimes and try to alleviate their anguish when being perceived by the Other as criminals. Both try to reconstruct their imaginary entities and that of the Other. Ry tries to annihilate his selfhood while committing crimes against his father, Marvin. For example, he perceives his toy, Scowler, as a living entity 
that brutally attacks Marvin. Scowler is perceived by Ry as the Other who must be blamed and take responsibility for the crimes Ry actually commits (Kraus $2013,247-248,257,259$ ). Violet also refuses to accept her identity as a criminal. She dismisses her free will and her sense of selfhood when she murders Harmony and Rachel. Furthermore, she alienates her hand from her entire being and blames the separate and, in a sense, disembodied hand for committing the crime. She rationalizes that her hand as it holds the crime weapon in order to stab the victims is not controlled by her. Violet posits that there is an external force, which completes the actual crime, denying her freedom of choice to commit the murder (Suma 2015, 260). In addition, Violet avoids accepting her criminal act through her imagination: she perceives her close friend, Ori, as the murderer and blames Ori for the crime (Suma 2015, 262263). Both Violet and Ry refuse to acknowledge their freedom to attack the Other and are thus not responsible for their crimes. They would like to solidify their social entities as decent individuals, dismissing the possible construction of their identities as criminals through the vehicles of their murderous acts. Both form imaginary situations in order to escape from the consequences of their wrongdoing and to avoid the oppression of the Other, who will perceive them both as offenders (Kraus 2013, 172, 219-220, 247-278, 257-259; Suma 2015, 26o-263). In contrast to the previous critiques, which underscore criminal characters' strong autonomy in committing crimes (Chapman 2004, 216-217; Horsley 2005, 134-136; Knight 2004, 197; Makinen 2006, 150-152), the findings in this article reveal that the criminal protagonists have a strong sense of autonomy in constructing the meanings of their entities and existence in the various crime-related contexts, especially when they try to abandon their former entities through their imagination and when they disregard the existence of the Other. The protagonists also use their imagination to palliate their sense of anguish or despair from the Other's judgments of their criminality and from the contingency of their situations.

Based upon the findings of my literature review, it can be seen that critics have also noted how protagonists who are crime investigators possess certain characteristics, such as mental strength, rationality, intelligence or specialized skills, which enable them to unriddle crime mysteries (Gregoriou 2007, 141-144, 146-148; Horsley 2005, 22-24, 33-34; Knight 1980, 83; Knight 2004, 170; Routledge 2010, 325-329; Scaggs 2005, 26-29, 59-6o). These positive characteristics of the detective protagonists may indicate a stereotypical depiction of them as heroic individuals. Nevertheless, it appears upon closer examination that the construction of the Self's identity is changeable, and the Self also tends to act in bad faith. That is, although protagonists who attempt to solve 
crime mysteries appear to have the free will to act or possess certain qualities for solving crime mysteries, they also have difficulty in making decisions and avoid responsibility for their actions. Hence, the detective protagonists may not always act admirably or may fail effectively to solve their problems. For instance, in The Interrogation of Gabriel James, the detective protagonist, Gabriel, at the beginning seems to be interested in investigating the crimes related to Raelene's family. However, his investigation becomes ineffectual since he fails to cope with the anguish caused by the Other's judgment upon him as a wrongdoer, and he fears that his investigation may negatively affect Raelene's life (Price 2010, 77, 58, 118-124, 129). Consequently, Gabriel tries to lessen his anguish through his imagination by destroying the Other's identity and through his isolation from his antagonists (Price 2010, 137-139, 142-143). In The Silence of Murder, the detective protagonist, Hope, also desires to prove that her brother, Jeremy, has not murdered Coach Johnson. However, Hope fixates her perception of the criminals' identities and uses her imagination to reconstruct possible suspects and crime incidents according to her own willto-power (Mackall 2011, 37, 168-169, 252, 281-282). Consequently, she fails to evaluate the crime-related situations realistically, disregarding the fact that the construction of an individual's identity can be dynamic. Similar to Gabriel, Hope can diminish her anguish or fear from the crime events only through her imaginary recreation of the Other's identity or the various crime-related situations (Mackall 2011, 168-169). Both protagonists show their sense of anguish or despair when experiencing the contingency of life or when facing their various traumatic situations; these situations give rise to and exemplify important existential elements of the human condition, which individuals have to endure or encounter. Moreover, the protagonists are portrayed as individuals who desire to investigate the crimes but who fail to construct significant qualities, such as strong will, rationality and other special abilities to effectively solve crime mysteries. The protagonists' denial of their innate freedom and responsibility for their actions prevents them from constructing their authentic identities as effective crime investigators. These depictions of both detective protagonists can reflect the fact that individual entities are not always static or consummate. The Other also has free will to perceive the protagonists as transgressors and offenders - or may actually treat them as victims.

Moreover, the findings indicate that victimized protagonists are portrayed as individuals, who strongly disregard their free will in order to take responsible actions. They tend to have a higher degree of acting in bad faith when compared to protagonists who are depicted as criminals and detectives. In The Sin Eater's Confession, the protagonist, Ben, is depicted as a victim of sexual 
discrimination (Bick 2013, 91-92). Feeling oppressed by how the Other regards him as Jimmy's sexual partner, Ben tries to isolate himself from Jimmy or even desires to hurt him (Bick 2013, 41-45, 61, 76, 80-82). To diminish his personal anguish, caused by the Other's gender prejudice against him, Ben perceives his hands used for touching Jimmy's hair as objects, which are not controlled by his will. Ben also tries to date his female classmate, Brook, to avoid criticism from the Other (Bick 2013, 72, 84). After Jimmy is mysteriously murdered, Ben suffers from the fear of being judged by the Other as a criminal. Consequently, he imagines himself in a situation with an alibi and wants to destroy his personal artifacts, which he perceives as sources of criminal evidence against him (Bick 2013, 113, 129-133). The imaginary construction of his situation, as related to Jimmy's murder, underscores Ben's acts of bad faith: he tries to solidify his sense of selfhood as an innocent person and avoids accepting the painful reality that the Other also has the free will to perceive his entity according to its own will.

Accordingly, in All the Truth That's in Me, the protagonist, Judith, objectifies her entity as being-in-itself and alienates herself from the Other during her traumatic predicament. Similar to Ben, Judith perceives her body as a passive object in sexually-related situations (Berry 2013, 86-87, 95, 176, 182-183). While Ben refuses to perceive his hands as parts of his body when he and Jimmy become physically close, Judith acts in a desensitized manner several times as though she were a mere object when she is sexually abused by the colonel and her schoolteacher. This suggests that both protagonists avoid being responsible for their own actions. They choose to be passive, letting their abusers suppress them. However, towards the end of the story, with mental support from Maria, Judith can eventually reconstruct a worthwhile meaning for her existence and selfhood, building a promising relationship with her childhood sweetheart, Lucas. As for Ben, he is depicted as the helpless victim of sexism and becomes the prime suspect for Jimmy's death right up until the end of the story. The portrayal of both protagonists indicates that although the Other dominates the construction of the Self's entity and existence, ultimately, the Self can still have the free will to resist the Other's dominance and form a more meaningful construction of its existence and identity.

\subsection{The Protagonists' Spatial Condition}

The Self's sense of freedom and its actions in bad faith can be depicted variously in different spatial contexts. For example, in the space categorized as existential outsideness, the criminal protagonists, Ry and Violet, lose their spatial sense of belonging and freedom. Ry becomes oppressed at home and on the farmland; these places are constructed as violent spaces, where his father 
abuses him and commands him to do vigorous chores and to mistreat his mother (Kraus 2013, 3-7, 12-13, 46, 102-103, 188, 230-232, 266). As for Violet, her sense of freedom is delimited in public spaces such as the theatre and the dancing rehearsal room, where she feels existentially outside and becomes conscious of her criminality (Suma 2015, 14-15, 76, 79, 90, 242-245). In both liminal and carnivalesque spaces, both criminal protagonists leave their former selves as innocent individuals and construct their new selves as offenders. For example, in natural places such as woods, the construction of Ry's criminality is portrayed: Ry can create a stronger sense of belonging in the forest, Black Glade, and identifies himself as his toy, Scowler, in order to fight with his father. He also imagines that his other toys mentally support him (Kraus 2013, 65-75). The fluidity of this natural space allows Ry to abandon his former self as an innocent son and to construct a new self as a monstrous fighter in the form of his toy figure. Similarly, Violet commits her crime in a natural zone: she murders Harmony and Rachel in an excluded area of the woods where vines and trees are interwoven to form a mysterious tunnel (Suma 2015, 14, 262-263). Violet abandons her former self as a well-known ballerina and constructs her new identity as a vengeful murderer. Both criminal protagonists resist the domination of their antagonists in the space of wilderness, where laws or social rules are not applicable.

Several critics have indicated how natural places in crime and mystery fiction are portrayed as an unsafe space which can challenge the protagonists' sense of freedom in dealing with their obstacles (Blum 2010, 90-92; Boesky 2010, 190-191; Leane 2016, 30-39). The existential approach employed here further shows that natural places can also offer the protagonists a spatial sense of belonging in which to construct their criminality and offer them a more pronounced sense of freedom to commit their crimes. Both Ry and Violet temporarily suspend their social identities in isolated natural zones and as a result of the rural locale, feel free to attack their antagonists. In a natural space, binary oppositions such as human vs inhuman and heaven vs hell are depicted so as to reinforce Ry's dilemma in choosing to sustain his innocence or carrying out his criminal acts. Ry perceives his toy figure, Jesus Christ, as his mental aid for coping with his fear, whereas he perceives another toy figure, Scowler, as a powerful entity which can overcome his father's dominance. Ry also blames Scowler for his violent attacks instead of admitting his own agency in these aggressive acts (Kraus 2013, 71-81). Additionally, in the natural tunnel, Violet chooses to perceive her hand holding the crime weapon as a mere thing which is not a part of her body; thus, she can freely disregard her agency in this criminal act (Suma 2015, 26o-262). Natural places offer a liminal zone where both criminal protagonists can gain a sense of freedom to dismiss their former 
selves and to recreate imaginary identities in order to diminish their anguish in crime-related situations.

For Gabriel and Hope, public and domestic places can make them feel particularly alienated and unsafe. For instance, in a restaurant named Smokey's, when Gabriel tries to tell his mother about the crime he has discovered at Ray's house, he feels very tense, perceiving her as a snake, which is trying to attack him and occupy his space (Price 2010, 101-102). At school, Gabriel loses his sense of belonging and feels frightened after learning about the events of hate crimes that occur. He trusts no student or teacher, thus being unable to share important information he suspects regarding the crime (Price 2010, 18, 121, 127128). As for Hope, she also finds public places alienating. In the restaurant Hope works at, she feels intruded upon by a reporter, who tries to gain information about her brother's trial case. Acting in bad faith, Hope hides in the restaurant to avoid meeting the reporter (Mackall 2011, 97, 146-150). A domestic place like home also forms space in the mode of existential outsideness. Gabriel finds his home very oppressive and wants to destroy his mother's belongings. He feels extremely alienated at home after learning about his mother's sexual affair with the criminal, Ray (Price 2010, 23, 158, 162-163). Similarly, Hope perceives home as an unsafe space. She mentions how her brother is abused by their mother. Hope also feels threatened due to her receiving harassing phone calls from a stranger who threatens her in order to stop the investigation of Coach Johnson's case. Moreover, Hope is full of fear when witnessing a white truck which mysteriously drives past her house many times (Mackall 2011, 16, 92-94, 116, 202-203, 216-218). These factors indicate that the protagonists' identities as crime investigators cannot be fully developed in public and domestic places. Since the Other takes control of these places, the protagonists lose their spatial sense of freedom and security. They alienate themselves from the objects—as well as people-in these places.

Crime sites also form space in the mode of existential outsideness, where Gabriel and Hope act in bad faith. The characteristics of being an effective detective (such as bravery and intelligence), are not apparently instantiated, whereas their cowardice and fear of making choices become apparent. When Gabriel reaches Ray's house, he regrets having put himself in this risky situation. As he witnesses the piles of dead dogs and the nudity of Ray's abused children, Gabriel wishes he could get out of this abnormal and frightening place. In bad faith, he imagines that he could bury his car so that no trace of him would be detected by the criminal (Price 2010, 59, 93-97). As for Hope, when she is at the crime site, the barn where Coach Johnson is murdered, she is uncertain if she has made a good choice by being there. She perceives the place as extremely frightening and imagines the existence of supernatural beings, the sound of 
thunder, a dark pool and even the smell of the victim's blood. She feels that she cannot control her fearful perception of this place, which is related to the crime (Mackall 2011, 45, 163, 166, 169). It thus appears that crime sites can stimulate uncontrollable fear in the detective protagonists. Their decision-making is ineffective in solving crime mysteries as they perceive that the places and people are harmful to their being. Hence, these places are not of a modality to enhance the construction of their identities as brave, rational and skillful detectives. Being in these unsafe places, the protagonists can sense how their lives may be contingent and feel anguish in making decisions that deal with unpredictable contexts. Therefore, they are depicted as cowardly individuals in these crime scenes.

Concerning the spatial construction of the victimized protagonists' entities, Ben and Judith are depicted as passive individuals, especially in public and natural places. At school, Ben is discriminated against as a homosexual and is accused of killing Jimmy (Bick 2013, 53, 64-65, 182-183). Similarly, school forms an oppressive space for Judith where she is ridiculed by her classmates because of her verbal disability. She is also sexually harassed by her schoolmaster (Berry $2013,174,192,211)$. Furthermore, another public place which is categorized as a zone of existential outsideness is the coffeehouse named Cuppa Joy, where people gather for religious activities. The coffeehouse is depicted as a church, where the good are welcomed, while the bad are punished. Ben feels that the people there treat him as a sinner because they assume that he has sexually abused Jimmy and murdered him. Ben tries to get out of this church-like coffeehouse when the pastor forces him to confess his sin (Bick 2013, 20-21, 251252). Similarly, Judith is devalued in the church of her community, which is depicted as a sacred place for moral people only. Like Ben, Judith is unfairly judged by the people. She feels spatially excluded from the church's space, since the people perceive her as a sinful prostitute (Berry 2013, 228, 238-239).

In natural places, both protagonists also lose their spatial sense of belonging. When Ben finds out in the woods that Jimmy has been murdered, Ben becomes full of fear, imaging how the black sky is related to Jimmy's blood. The woods become dangerous and mysterious, forcing Ben into becoming too frightened to take any serious action (Bick 2013, 102-104, 108). Correspondingly, when Judith stays in the woods with the colonel, she is depicted as his sex object and reacts as a passive object, without any emotion while he abuses her (Berry 2013, 19, 30, 95). In similar spatial situations that both protagonists confront, the woods are constructed as a mysterious and harmful zone, where crimes can be freely committed without legal punishment; furthermore, the protagonists are depicted as helpless victims who do not take practical actions 
to alleviate their fear or anguish. The Other can take control of the natural, as well as the public space, whereby Ben and Judith feel victimized.

Through the analysis of these crime and mystery novels, the evidence suggests that all protagonists experience various challenges in acknowledging their freedom in relation to socially and spatially constructing the authentic meaning of their subjectivity and existence in relation to the Other-and as a result they avoid taking complete responsibility for their actions. In their various traumatic or critical situations, they express their anguish, fear and despair, while making existential choices. Consequently, they cannot perceive or evaluate their situations realistically. They have difficulty in admitting the dynamic construction of their identities in accordance with those of the Other. In bad faith, the protagonists tend to escape from their undesirable situations through their imagination about their past, future or their currently unusual circumstances. While experiencing the contingency of their relative situations, they attempt to solidify their entities and the entities of the Other in order to sustain their sense of control. The Other's dominance also prevents the protagonists from acknowledging their free will to responsibly take effective action. The criminal and detective protagonists are also depicted as weakwilled individuals, being subjected to the oppression of the Other. Among the two protagonists who are categorized as the victims of crimes, only one of them can reconstruct an authentic sense of selfhood in the end. The narratives reflect how the construction of human subjectivity can be dynamic or static, depending on individuals' choices and their interrelationships with the Other. Concerning the protagonists' spatial condition, they lose their sense of freedom in space classified as existential outsideness, since this kind of space tends to be controlled by the Other, who devalues the protagonists' identities. In space classified as existential insideness, protagonists can maintain their autonomy, especially when they can isolate themselves from their antagonists. Also, the protagonists can temporarily postpone their decision-making or dismiss any responsibility for their criminal acts, leading to the alleviation of their anguish and fear. Finally, in liminal and carnivalesque spaces, the protagonists' identities become equivocal and contingent, through the suspension of laws or social codes; consequently, they feel free to commit crimes or form imaginary situations to lessen their anguish or the fear of making existential choices. 
It has been suggested that various mysterious or crime-related contexts which reinforce or hinder the use of an individual's free will should be explored or examined. Future research could focus on fictional narratives related to supernatural or magical forces. A critical analysis could be conducted in order to compare or contrast the depiction of supernatural characters and human characters and to examine how these kinds of characters perceive their sense of freedom and autonomy in creating the meaning of their existence. The roles or functions of magic or supernatural powers can also be explored in order to illustrate whether characters who possess mysterious or supernatural forces act in bad faith or are responsible for their actions when they deal with critical or difficult situations. In terms of spatial contexts, it can also be useful to explore whether supernatural beings can spatially experience the contingency of life in the same degree or manner as human characters. Particular places portrayed in the supernatural world, such as mysterious natural areas and paradisal or hell-like zones could be examined in order to discover how spatiality can be important in the construction of characters' moral, immoral or even amoral behavior, as the characters experience the contingency of life. Significant findings from the above-mentioned research aspects may be constructive in reflecting upon the human condition or upon human experiences with regard to the relationship between the Self and the Other, human affliction and the fulfilment of human existence.

\section{Acknowledgements}

I am grateful to the Faculty of Humanities, Chiang Mai University and to Asst. Prof. Dr. Wayne George Deakin.

\section{References}

Ascari, Maurizio. 2007. A Counter-History of Crime Fiction: Supernatural, Gothic, Sensational. New York: Palgrave Macmillan.

Bakhtin, Mikhail Mikhailovich. 1984. Rabelais and His World. Translated by Hélène Iswolsky. Bloomington: Indiana University Press.

Berry, Julie. 2013. All the Truth That's in Me. London: Viking Books.

Bertens, Hans, and Theo D'haen. 2001. Contemporary American Crime Fiction. New York: Palgrave.

Bick, Ilsa J. 2013. The Sin Eater's Confession. Minneapolis: Lerner Publishing Group. 
Blum, Elizabeth D. 2010. "Natural Detective Work: Ideas about Nature in the Early Tom Swift Books." In The Boy Detectives Essays on the Hardy Boys and Others, edited by Michael G. Cornelius, 86-107. North Carolina: McFarland \& Company.

Boesky, Amy. 2010. "Solving the Crime of Modernity: Nancy Drew in 1930." Studies in the Novel 42 (1 \& 2): 185-201.

Chapman, Mark Christopher. 2004. "The Criminal Protagonist: Moral Collapse, Ethical Ambiguity, and the Pursuit of Happiness in Twentieth-Century American Crime Fiction." PhD diss., University of Texas at Dallas, USA.

Gregoriou, Christiana. 2007. Deviance in Contemporary Crime Fiction. New York: Palgrave Macmillan.

Hoffman, Megan. 2016. Gender and Representation in British 'Golden Age' Crime Fiction. Basingstoke: Palgrave Macmillan.

Horsley, Lee. 2005. Twentieth Century Crime Fiction. New York: Oxford University Press. Knight, Stephen. 1980. Form and Ideology in Crime Fiction. Basingstoke: Macmillan.

Knight, Stephen. 2004. Crime Fiction, 1800-2000: Detection, Death, Diversity. New York: Palgrave Macmillan.

Kraus, Daniel. 2013. Scowler. New York: Random House.

Leane, Elizabeth. 2016. "Unstable Places and Generic Spaces: Thrillers Set in Antarctica." In Popular Fiction and Spatiality: Reading Genre Settings, edited by Lisa Fletcher, 25-44. New York: Palgrave Macmillan.

Mackall, Dandi Daley. 2011. The Silence of Murder. New York: Knopf Books.

Macleod, Anne Scott. 1994. American Childhood: Essays on Children's Literature of the Nineteenth and Twentieth Centuries. Athens: The University of Georgia Press.

Makinen, Merja. 20o6. Agatha Christie: Investigating Femininity. New York: Palgrave Macmillan.

Price, Charlie. 2010. The Interrogation of Gabriel James. New York: Farrar, Straus and Giroux.

Relph, Edward. 1976. Place and Placelessness. London: Pion.

Routledge, Christopher. 2010. "Crime and Detective Literature for Young Readers." In $A$ Companion to Crime Fiction, edited by Charles J. Rzepka and Lee Horsley, 321-331. West Sussex: Blackwell Publishing.

Sartre, Jean Paul. 1948. Existentialism and Humanism. Translated by Philip Mairet and Carol Macomber. London: Methuen.

Sartre, Jean Paul. 1958. Being and Nothingness: An Essay on Phenomenological Ontology. Translated by Hazel E. Barnes. London: Methuen.

Sartre, Jean Paul. 2001. The Psychology of Imagination. London: Routledge.

Sartre, Jean Paul. 2007. Existentialism Is a Humanism. London: Yale University Press.

Scaggs, John. 2005. Crime Fiction. New York: Routledge.

Suma, Nova Ren. 2015. The Walls around Us. New York: Algonquin Books. 
Tuan, Yi-Fu. 1974. Topophilia: A Study of Environmental Perception, Attitudes, and Values. New York: Columbia University Press.

Turner, Victor W. 1969. The Ritual Process: Structure and Anti-Structure. Chicago: Aldine Pub.

Van Gennep, Arnold. 196o. The Rites of Passage. Translated by Monika B. Vizedom and Gabrielle L. Caffe. Chicago: University of Chicago Press.

Woolf, Mike. 1988. "Exploding the Genre: The Crime Fiction of Jerome Charyn." In American Crime Fiction: Studies in the Genre, edited by Brian Docherty, 131-143. London: Macmillan Press. 